\title{
Customized E-Learning for B2B Companies
}

\author{
http://dx.doi.org/10.3991/ijac.v7i2.3612 \\ T. Thomasma \\ Memarden Inc., Windsor, Canada
}

\begin{abstract}
Business-to-Business (B2B) companies have customers that are primarily other corporations. These companies have unique problems in workplace training. They must train their customers and their customers' employees. A B2B company may operate with only a few dozen employees, but they may need to help thousands of customers learn how to make best use of their product or service. Discussions with industry executives suggest an ideal training solution might include a number of features that are reviewed in this paper.
\end{abstract}

Index Terms - business-to-business, customer training, elearning.

\section{TRAINING AND Business-TO-Business COMPANIES}

B2B companies (companies whose customers are primarily other corporations) have unique problems in workplace training. They must train their customers and their customers' employees. A B2B company may operate with only a few dozen employees, but they may need to help thousands of customers learn how to make best use of their product or service.

The value to a B2B company in having well-trained customers is enormous: lowered support costs; improved customer satisfaction; increased customer engagement; lower churn; higher up-sell rate; and in this era of the Social Network - improved ratings and recommendations. All of these lead directly to the bottom line through reduced costs and increased sales.

Companies use face-to-face learning events, webinars, on-line videos, documents, and on-line courses to help their customers become expert users. These are effective methods, but they can be expensive. They can also require long lead time to produce, which can limit flexibility in addressing issues from the field in a timely way, or keep up with rapid innovation in the company's products and services.

Discussions with industry executives suggest an ideal training solution might include the following:

- Lesson Creation Speed

- Rich Content

- Engaging Interactivity

- Accessibility

- Reports and Monitoring

- Single-Sign-On and Co-Branding

- Cost Effective

- Flexible Business Model

\section{Characteristics Desired in Training SOlution}

Educating customers about a company's products is not the same as teaching someone how to write better essays or how to do algebra. There is no source of educational materials to directly use, simply because the product is unique. Producing the unique lesson materials that are required takes time and expense. The ability to create interactive lessons in a short amount of time is a valuable component of a training solution.

There is research showing that multimedia (sound, graphics, and video) produces better learning results and creates a more positive impression of the material that is taught than use of text only [1]. The training solution should provide the ability to include video, audio, images, documents (pdf, PowerPoint, Word) and text. Companies often have collections of media that they use for marketing purposes. It should be easy for companies to leverage these collections of media to produce engaging training for their customers.

Gamification provides an additional dimension of engagement and interactivity. Use of points, awards, leader boards and games with the teaching activities produces increases in engagement, understanding, and interest in the subject matter being taught [2]. A training solution that automatically creates activities, games, and quizzes from lessons can present learning content easily in the form of games. This produces a higher level of customer interaction with the company and its products.

It's best for training to occur as close to point of use as possible. Leading companies that have franchises schedule training for franchisees just before the opening of the new store, so that as much learning as possible can be retained and reinforced in the actual experience of operations. When the training solution is available everywhere, on all kinds of devices (cell phones to big screen displays and everything in between), then customers can take or retake the training at any time and place they choose. It's desirable that the training solution is completely web-based, with mobile versions that work on all relevant platforms. In fact, if customers are enabled to have full autonomy for free exploration, they may make use of on-line educational experiences even in leisure settings [3].

Customers have greater confidence in using products that they feel they really understand. The training solution should include the ability for customers to self-assess their progress and for the company to monitor customer activity in detail. Private on-line assessments that give immediate feedback about activity results and the difficulty levels of the learning challenges that are presented improve test scores [4].

Additionally, by following the results of customers' engagement with the training material, businesses gain insight into which features and design aspects of their products are most troublesome for the users, and which are the most usable. This is important input for the design of future products. 


\section{CUsTOMIZED E-LEARNING FOR B2B COMPANIES}

Since training is another opportunity for customers to engagement with the business, the experience should be consistent with the company's branding and image. The training solution should be co-branded with and support single sign-on with the company's web site or core application offering. Customers should be primarily aware of using the training solution. They should feel that they are making use of a valuable service that the business provides them.

The training solution should be cost-effective. Ideally, there should be little or no cost to produce the training lessons, and it should be possible to rapidly recover cost by modest customer fees, advertisement or other means as the lessons are delivered.

Businesses will need flexibility in business models that the training solution supports. They can pay directly for delivery of lessons, or their customers can be billed as they use lessons. The training solution should be flexible in setting up convenient payment arrangements and applying them in a way that is most effective for each business and its customers.

With current technology and insight into ways in which technology can improve learning it is possible to build a globally available e-learning platform that has the characteristics that executives of $\mathrm{B} 2 \mathrm{~B}$ companies have asked for.

\section{REFERENCES}

[1] A. Ioannou, S. W. Brown, R. D. Hannafin, and M. A. Boyer, "Can multimedia make kids care about social studies? The GlobalEd problem-based learning simulation," Computers in the Schools, vol. 26, pp. 63-81, 2009. http://dx.doi.org/10.1080/ 07380560802688299

[2] D. T. Hickey and M. J. Filsecker, "A quasi-experimental study of badges, incentives, \& recognition on engagement, understanding, \& achievement in Quest Atlantis," in Proceedings GLS 9.0. Games + Learning + Society Conference, C. C. Williams, A. Ochsner, J. Dietmeier and C. Steinkuehler, Eds. ETC Press, 2013, pp. $182-188$.

[3] S. Cilesiz, "Educational computer use in leisure contexts: A phenomenological study of adolescents' experiences in internet cafés," American Educational Research Journal, vol. 46, pp. 232274, March 2009. http://dx.doi.org/10.3102/0002831208323938

[4] A. A. Economides, "Conative feedback in computer-based assessment," Computers in the Schools, vol. 26, pp. 165-168, 2009. http://dx.doi.org/10.1080/07380560903095188

\section{AUTHOR}

T. Thomasma is with Memarden Inc., Windsor, Ontario 80305 N9A 6T5 Canada (e-mail: tthomasma@memarden.com).

Submitted 25 February 2014. Published as re-submitted by the author 08 June 2014. 